\title{
Exploration versus Exploitation: Leadership and the Paradox of Administration
}

\author{
William Burpitt \\ Love School of Business \\ Elon University
}

\begin{abstract}
Focused on small firms, this paper explores the effectiveness of transformational versus transactional leadership in responding to disruptive environmental change and the need for the firm to balance the exploitation of its existing domain against the need to explore new ventures and modes of operation. The study finds that firms under transformational leadership were more effective in the development of new products, markets, manufacturing and management systems, and new skills and capabilities and earned greater revenues in the process. The study finds the best overall financial performance among the small number of firms whose owners combine both types of leadership.
\end{abstract}

\section{Introduction}

This research explores factors that can stimulate small firms to take the actions needed to confront threats arising from discontinuous changes in their markets and traditional operations. Not all do so, even when the need is clear. A "primary cause" firms fail to take action resides within the firms themselves, with management that fails to respond as needed (Weitzel \& Jonsson, 1989: 93). One firm owner, interviewed in the conduct of this research, expressed a sentiment that was characteristic of many of his peers, "I know we ought to change, but it's just so darn hard to give up what you know. Even when we can see the business dropping off there is a real tendency to just work harder at what we're already doing."

Organizations naturally prefer predictable, incremental change to the risk and uncertainly associated with significant, transformative change (Benner \& Tushman, 2001; Gilbert, 2005; Tripsas \& Gavetti, 2000). Yet some do initiate significant change, change that touches a firm's markets, its products, even the capabilities that had long been the foundations of its past success. In large, diversified firms 'skunk works' or special divisions can take on the risk of venturing into new directions, allowing the parent firm to exploit the efficiencies of its traditional operations. But what of the small business owner who, lacking the resources of big firm, must find ways to balance these conflicting needs? This research explores the role of the small business owner in managing the conflicting needs of stability and change and the comparative influence of transformational leadership in the context of an industry struggling with foreign competition and the off-shoring of its traditional customer base. The types of changes undertaken and implications for financial performance are investigated. 


\section{Leadership Type and Organizational Change}

Research focusing on leadership must first contend with a wide variety of definitions. Yukl and Van Fleet (1992) note that leadership has been defined in terms of "individual traits, leader behaviors, interaction patterns, role relationships, follower perceptions, influence over followers, influence over task goals, and influence over organizational culture (1992: 148)." These authors settle on a definition that matches the emphasis of the present research, defining leadership in terms of their influence over objectives and strategies and the willingness of people in the organization to work toward the implementation of such strategies. Much of our understanding of leadership is derived from the substantial literature that has focused on two general types of leader behavior, initiating structure and consideration. There are good reasons for the enduring influence of this conceptualization. These two visions of leadership capture the familiar contrast of democratic versus autocratic, directive versus participative, and task versus relationship orientation, the one set dealing with clarification and structuring of work related tasks and the other with behaviors intended to manage relations between the leader and the work group (Howell \& Avolio, 1993). The literature on these two types was extended and enriched with Bass' observation (1998) that many leader behaviors go beyond a transactional exchange between the leader and follower. While a wide range of behaviors are encompassed by the initiating structure / consideration constructs, another type of leadership, transformational, can move followers beyond a transactional relationship with their work, with the result that they may transcend their own immediate self-interest in pursuit of larger, organization-wide goals (Keller, 1992; Seltzer \& Bass, 1990).

These two leadership types, transactional and transformational, are not mutually exclusive. Both types of behaviors may be enacted by the same leader at different times, in different amounts, in different circumstances (Bass, 1998). Many leaders characterized as transformational also engage in transactional behaviors. Nor is it implied that transformational leadership negates the value of transactional leadership. Leaders operating in a transactional mode emphasize clarification of tasks and expectations, provide structure, offer rewards in exchange for subordinates' meeting performance goals, and perhaps threaten intervention if they do not (Viator, 2001). Behaviors such as these are part of an effective manager's tool kit and are clearly useful when applied appropriately. When operating in a transformational mode leaders work to "increase the level of followers' awareness for valued outcomes by expanding and elevating their needs and encouraging them to transcend their self-interest" (Bycio, Hackett \& Allen, 1995: 468). Behaviors such as these are desirable, particularly when conditions favor a shift from established routines towards a posture that embraces change and the acquisition of new knowledge and skills (Vera \& Crossan, 2004).

The situation faced by the firms in this study, industry decline brought about by a steady erosion of market due to the off-shoring of customers and low-cost foreign competition, calls for a departure from reliance on established routines and 
procedures in favor of venturing in new directions. This is a context where transformational leadership should provide a distinct advantage (Vera \& Crossan, 2004; Viator, 2001). "Particularly in times of change," altering a firm's established practices is "best suited to transformational leadership" while in times of stability organizational needs are "best suited to transactional leadership" (Vera \& Crossan, 2004: 226).

Managers are rarely faced with stark either / or situations however, but rather equally pressing, conflicting demands. Theory and empirical evidence suggests that the most effective managers apply both transactional and transformational skills (Avolio, Bass, \& Jung, 1999; Quinn, 1988; Rowe, 2001). Organizations facing significant change must balance the need to refine and exploit existing skills while they work to acquire and apply new skills (Tushman \& O'Reilly, 1996; Vera \& Crossan, 2004). Leaders operating in a transactional mode encourage employees to maximize an organization's current capabilities, with an emphasis on extracting greater efficiencies from existing routines and practices (Crossan, Lane, \& White, 1999). In a transformational mode leaders create a vision of organizational change, minimize resistance to that change, all while encouraging members to explore, acquire, and adopt new ways of doing the work of the firm (Bass, 1998; Tichy \& Ulrich, 1984).

The focus of this research is on the relationship between the leadership manifested by a firm's owner and the organization's responses to significant, threatening changes in the external environment. Specifically, it explores the relationship between transactional and transformational leadership and a number of variables important to organizational survival and success in times of substantial external change. These variables include entry into new markets, the development of new products, new manufacturing and management systems, and the development of new organizational skills and capabilities. It also explores the linkages between leadership behavior, organizational change, and financial performance. Each of these will be discussed in turn.

\section{Hypotheses}

Leaders identified by their subordinates as transformational should be more strongly associated with organizational change than leaders perceived as transactional in behavior and style (Howell \& Avolio, 1993; Keller, 1992; Pawar \& Eastman, 1997). Viator has suggested that "transformational leadership is one way for organizations to respond to increased economic competition" (2001: 101) and that transformational leaders will be more likely to stimulate the change and innovation that is needed for effective organizational revitalization (Tichy \& Devanna, 1986). As noted by Bass, "the real movers and shakers in the world are transformational" (1990: 23). It is their ability to shift organizational emphasis from refinement and exploitation of current knowledge towards the exploration and acquisition of new learning that makes such leaders valuable, "particularly in times of change" (Vera \& Crossan, 2004: 226). The value of transformational leaders as agents of change resides in articulating and instilling new values and reshaping organizational culture, a "process of envisioning, energizing, and 
empowering organizational members" (Pawar \& Eastman, 1997: 82). This corresponds to Jansen's (2004) conceptualization of change-based momentum, where the leader's effort is directed towards changing the organization's strategy or trajectory. If the organization is to pursue a strategy of change, efforts directed at maintaining the current practices and policies must be "redirected, replaced, or overcome by momentum in a new direction" (Jansen, 2004: 277). This calls for transformational leadership.

All organizations learn, of course, either learning which refines existing knowledge and skills and results in increasingly efficient and reliable routines or learning that focuses on the acquisition of new skills and yields increased flexibility and adaptivness (Fiol \& Lyles, 1985; Sitkin, 1992). Learning of the later type will better equip a firm with the capabilities needed to develop new products and new markets. Transformational leaders should be more effective in stimulating development of the such learning (Vera \& Crossan, 2004), in part because they provide organizational members a greater sense of empowerment, enhancing the sense of their own competence and ability (Krueger, 2000). The impact of such leadership should be particularly striking in the case of smaller firms where the owner exerts influence directly on his or her subordinates, unlike the situation in larger, more complex firms, where the influence of the president or CEO can be filtered through distance and layers of management.

Transformational leaders also allow greater autonomy, granting a freedom of action that results in a higher degree of variance in practice and outcome, experience that in turn enhances the organization's ability to adapt and acquire new knowledge and skills (McGrath, 2001).

Hypothesis 1: Transformational leaders will be positively associated with the development of new products and new markets.

Hypothesis 2: Transformational leadership will be positively associated with the development of new organizational systems, new manufacturing systems, and new organizational skills and capabilities.

Compared to transformational leadership, transactional leaders focus more on the efficiency of existing operations than on the acquisition of new capabilities (Boal \& Bryson, 1988; Shamir, House, \& Arthur, 1993). This can result in stasisbased momentum where the energy and effort of the leader is directed at exploiting the organization's current strategy, capabilities, and markets (Jansen, 2004). In conditions of stability organizations benefit from such an orientation, exploiting the rewards of "formal and precise specification of employee contributions, vigilant assessment of actual contributions, and provision of performance contingent rewards" (Pawar \& Eastman, 1997).

However, the characteristics that define transactional leadership, the precise definition of tasks, routines, responsibilities, and expectations (Viator, 2001) can be dysfunctional in periods of dynamic change, narrowing the opportunity for search and exploration, reinforcing a perceptual frame that excludes information that does not conform to existing practice and expectation (McGrath, 2001). In the case of small owner-led firms such as those represented in this study, any 
bias towards increased exploitation of the familiar may be even greater as the conservatism that might characterize any firm facing disruptive change is reinforced when the value of the owner's own career experience is being challenged. Even when aware of external change and the need to alter strategy and internal operations such a leader may continue to focus attention on exploiting those tasks that the firm knows best. "Operating within an existing system, transactional leaders seek to strengthen an organization's culture, strategy, and structure" (Vera \& Crossan, 2004: 224), where the returns to exploitation "are positive, proximate, and predictable" (March, 1991: 85). Hypothesis 3: Transformational leadership will be positively associated with an organization emphasis on exploration while transactional leaders will be positively associated with an emphasis on exploitation.

Insofar as the firms examined in this study are representative of businesses facing industry wide decline we would expect firms under the management of transformational leaders that had developed new products, new markets and new organizational skills would be more likely to report new sources of revenue and overall positive changes in revenue as new sources were developed. In contrast, we would expect that firms under transactional leadership that remain committed to familiar products and markets would be less likely to develop new products and markets and thus less likely to exhibit new sources of revenue or experience overall increases in revenue.

Research regarding the relationship between exploitation versus exploration strategies and financial performance in conditions of industry decline is mixed. Parker and Helmes (1992) found that higher financial performance was most often associated with efficiency oriented exploitation. In a study of boarding schools Recker, Goldsby and Neck (2002) found that the schools that survive and prosper combined an emphasis on controlling cost while at the same time developing innovative, creative responses to the changes in the environment. Stopford and Baden-Fuller (1990) found that firms that did best when facing foreign competition in the British knitwear industry were those that had learned how to balance exploration and exploitation. Kalafasky and MacPherson (2002), in a study of the US machine tool industry, reeling from low cost foreign competition, found that the recovery of revenue and profits was associated with the exploration and development of new niches, new capabilities, and increased levels of product and process innovation. This research explores the relationship between exploration and exploitation and firm performance in the context of small, owner-led firms, a large population whose members are particularly vulnerable to systemic change.

Growth in revenue does not assure growth in profits, however. Managers confronting industry decline are faced with a difficult, often conflicting choices. They can exploit their existing product and market domains with a focus on efficiency or explore the development of new products and new markets outside an existing domain (Anand \& Singh, 1997; Kalafsky \& MacPherson, 2002). These choices represent a struggle to balance "profits for today and flexibility to adapt for tomorrow" (Volberda, Baden-Fuller, van den Bosch, 2001: 159). 
Comparatively few firms are able to maintain a balance of the two (Tushman \& O'Reilly, 1996). Exploitation creates reliability through refinement of familiar routines (Holmqvist, 2004). Such routines, "tightly aligned" with a firm's experiences and "deeply ingrained" in organizational cognitions (Gilbert, 2005: 742), are often preferred to new product and new market development, activities that can combine a reduction in efficiency with increased risk and potential for loss (Anand \& Singh, 1997; Hitt, Keats, \& DeMarie, 1998; Kalafsky \& MacPherson, 2002; Volberda, Baden-Fuller, van den Bosch, 2001). Hypothesis 4: Transformational leadership will be positively associated with new sources of revenue and with an overall increase in revenue.

Hypothesis 5: Transactional leadership will be positively associated with profit.

\section{Data Collection}

Firms providing supplies, tools, services and materials to the furniture industry formed the sample for the study. The advantages of a single industry focus has been observed by researchers (Miller, Greenwood \& Hinings, 1999; Rouse \& Daellenbach, 1999) who note that a single industry sample can help control for problems such as common factor markets and inter-industry variance (Barney, 1986; Gordon, 1991; Mascarenhas \& Aaker, 1989). The firms were selected from a manufacturing directory listing SIC codes, years of operation, annual sales ranges, and number of employees. All were located in the southeastern U.S. To be included in the survey, firms were screened for three criteria. First, only small firms were included. The firms sampled in this study averaged 17 employees and ranged in size from 11 to 33 employees. Next, only stand-alone firms were chosen. This was done to ensure that any actions initiated in response to environmental change were determined at the level of the target firm. Finally, to ensure that the firms studied had experienced the recent upsurge in foreign competition only firms that had been in operation a minimum of seven years were included.

Data for this study was collected using a web-based survey. Initial contact was made with the owners of 138 firms by letter followed by telephone contact, a time consuming process undertaken to stimulate participation. The owners of 116 firms agreed to participate. Those declining cited work pressures. Survey results were received from 91 of these 116 firms. Of the remaining 25 nonparticipating firms either data was not returned at all or insufficient data (defined as no more than two completed surveys) was returned. Four-hundred and twenty-five surveys were returned from these 91 firms, a number that includes each of 91 firm owners plus 334 employees. These firms had been in operation a minimum of 11 years and reported average annual revenues of approximately $\$ 8$ million. Sixty-eight percent of respondents were male. Average tenure with their respective firms was 8 years. Survey respondents were drawn from both managerial (66 percent) and staff (34 percent) ranks. The comparatively high participation rate, 78 percent, may be attributable to the convenience and the confidentiality of the web-based survey design. 
Measures of transformational and transactional leadership was based on the Bass MLQ measure $(1985,1998)$ as adapted by Vera and Crossan $(2004)$. This scale (shown in the appendix) contains 12 items measuring transformational leadership, grouped under four headings: charismatic leadership, inspirational leadership, intellectual stimulation, and individualized consideration.

Transactional leadership was measured with 6 items, grouped under two headings: contingent reward and management by exception. Survey participants indicated their assessment of the firm owner's leadership on each item using a 5point Likert scale, anchored by $1=$ does not describe the behavior of the firm owner at all to $5=$ describes the behavior of the firm owner to a very high degree. These leadership measures were only provided by the employees of the firms. Owners did not complete these scales. Thus they reflect and represent the perceptions of the firms' employees, management and staff, of the leadership style and behaviors of the firms' owners. The scores of individual respondents were averaged to produce a firm level score. There are both advantages and disadvantages in such averaging. It can, on one hand, obscure real differences in the perceptions of individual members regarding the leader's behaviors. On the other, "averaging ratings from several subordinates tends to reduce the effects of perceptual biases and rating errors (leniency, attributions, differential opportunity to observe leader) in behavior ratings made by individual subordinates (Yukl \& Van Fleet, 1992: 184)." Measures of organizational change in the previous five year period were based on a scale developed by Robbins and Pearce (1992). This scale measured organizational change in five areas: markets, products, manufacturing systems, management and organization systems, and changes in skills and distinctive competencies. For each of these areas, respondents indicated degree of change by circling a number on a continuum, anchored on one end by $1=$ no change to $5=$ complete change. An example is below.

Products. Over the last five years, describe any change in the firm's product offering defined in terms of breadth, level of customization, and the actual products themselves.

\section{$\begin{array}{lllllll}\text { No Change } & 1 & 2 & 3 & 4 & 5 & \text { Complete Change }\end{array}$}

All 425 participants, 91 owners and 334 employees, completed the measures of these five change areas. A single item scale developed by Robbins and Pearce (1992) measured the organization's emphasis on exploitation versus exploration. This measure employed a 5-point Likert scale, anchored by 1 = Primary efficiency oriented with belt tightening and refinement of existing operations and $5=$ Primary exploration oriented with changes in technology, products, or markets. All 425 respondents also completed this measure. A second measure of a firm's emphasis on exploitation versus exploration was captured using a scale item measuring the sources of a firm's revenues. Source of revenue was measured using a 5 -point scale anchored by $1=$ all revenue from traditional, long term sources and $5=10$ percent or more of revenue derived from products and markets that are new to the firm, a percentage that has been growing. 
Changes in revenue and profit were measured on a 5-point scale anchored by 1 = a decline of greater than 10 percent over the five years leading up to the study and $5=$ increase greater than 10 percent. The measures of sources of revenue and changes in the level of revenue and profit were collected from the 91 firm owners only. These measures were derived from a scale developed by Moni (1998).

\section{Results}

Table 1 below lists the means, standard deviations, and T-statistics for each of the variables. The data in Table 1 is organized in two groups, firms in which the owner received what are defined as high transformational scores (44 firms) and those in which they received low transformational scores (47 firms). High versus low scores in transformational leadership are defined as above or below the mean score of 3.31 for transformational leadership. The means displayed in Table 1 provide evidence supporting Hypotheses 1, that transformational leadership will be positively associated with entry into new markets and development of new products, and Hypothesis 2, that transformational leadership will be positively associated with the development of new organizational and management systems, new manufacturing systems, and the acquisition of new skills and capabilities. In those firms where the employees scored their firm's owner high on transformational leadership t-tests indicate that the means for each of these five variables were significantly higher than were the means on these variables in the firms where the average scores on transformational leadership were low, below the mean.

\section{Table 1: Average Variable Scores Per Leadership Type}

\begin{tabular}{|c|c|c|c|c|c|}
\hline Variables & $\begin{array}{l}\text { Transformational } \\
\text { Leadership }\end{array}$ & Mean & s.d. & $\mathrm{T}$ & Sig. \\
\hline \multirow[b]{2}{*}{ Source of Revenue } & High Transformation & 4.05 & .68 & \multirow[b]{2}{*}{26.63} & \multirow[b]{2}{*}{.00} \\
\hline & Low Transformation & 2.16 & .76 & & \\
\hline \multirow[b]{2}{*}{ Exploration Orientation } & High Transformation & 3.99 & .66 & \multirow[b]{2}{*}{24.57} & \multirow[b]{2}{*}{.00} \\
\hline & Low Transformation & 2.31 & .76 & & \\
\hline \multirow[b]{2}{*}{ New Market Development } & High Transformation & 3.98 & .66 & \multirow[b]{2}{*}{25.66} & \multirow[b]{2}{*}{.00} \\
\hline & Low Transformation & 2.18 & .76 & & \\
\hline \multirow[b]{2}{*}{ New Product Development } & High Transformation & 3.98 & .59 & \multirow[b]{2}{*}{37.93} & \multirow[b]{2}{*}{.00} \\
\hline & Low Transformation & 1.48 & .56 & & \\
\hline \multirow[b]{2}{*}{ New Mfg. Systems } & High Transformation & 3.87 & .63 & \multirow[b]{2}{*}{9.04} & \multirow[b]{2}{*}{.00} \\
\hline & Low Transformation & 3.32 & .59 & & \\
\hline \multirow[b]{2}{*}{ New Management Systems } & High Transformation & 4.03 & .65 & \multirow[b]{2}{*}{32.16} & \multirow[b]{2}{*}{.00} \\
\hline & Low Transformation & 2.08 & .61 & & \\
\hline \multirow[b]{2}{*}{ New Skills \& Knowledge } & High Transformation & 4.02 & .68 & \multirow[b]{2}{*}{29.76} & \multirow[b]{2}{*}{.00} \\
\hline & Low Transformation & 2.13 & .64 & & \\
\hline \multirow[b]{2}{*}{ Change in Revenue } & High Transformation & 3.80 & .63 & \multirow[b]{2}{*}{17.45} & \multirow[b]{2}{*}{.00} \\
\hline & Low Transformation & 2.31 & .85 & & \\
\hline \multirow[b]{2}{*}{ Change in Profit } & High Transformation & 2.82 & .64 & \multirow[b]{2}{*}{7.73} & \multirow[b]{2}{*}{.00} \\
\hline & Low Transformation & 2.45 & .87 & & \\
\hline
\end{tabular}


The data in Table 1 also provides support for Hypothesis 3, that transformational leadership will be positively associated with an organizational emphasis on exploration while transactional leadership will be positively associated with an emphasis on exploitation. Two scales provide an indication of such an emphasis. The first is a five point scale measuring an emphasis on exploitation or exploration. The second scale that indicates the relative emphasis on exploration versus efficiency is a measure of the firm's source of revenue, where

\section{Table 2: Scores per Leadership Type by Transformational and Transactional}

\begin{tabular}{|c|c|c|c|c|}
\hline & \multicolumn{2}{|c|}{ Quadrant 3 (24 firms) } & \multicolumn{2}{|c|}{ Quadrant 4 (20 firms) } \\
\hline \multirow{5}{*}{ High } & Transformational Score & 4.39 & Transformational Score & 4.57 \\
\hline & Transactional Score & 2.63 & Transactional Score & 4.54 \\
\hline & Revenue Change & 3.73 & Revenue Change & 3.86 \\
\hline & Profit Change & 2.38 & Profit Change & 3.26 \\
\hline & Source of Revenue & 4.08 & Source of Revenue & 4.02 \\
\hline \multirow{6}{*}{$\begin{array}{r}\text { Transformational } \\
\text { Leadership } \\
\text { Scores }\end{array}$} & Explore/Exploit & 4.04 & Explore/Exploit & 3.93 \\
\hline & New Markets & 4.06 & New Markets & 3.94 \\
\hline & New Products & 4.02 & New Products & 3.93 \\
\hline & New Mfg. Systems & 3.88 & New Mfg. Systems & 3.86 \\
\hline & New Mgmt. Systems & 3.92 & New Mgmt. Systems & 4.13 \\
\hline & New Skills & 3.90 & New Skills & 4.14 \\
\hline \multirow{8}{*}{ Average $=3.31$} & Transformational Score & 2.41 & Transformational Score & 2.36 \\
\hline & Transactional Score & 2.07 & Transactional Score & 4.37 \\
\hline & Revenue Change & 1.74 & Revenue Change & 2.87 \\
\hline & Profit Change & 1.93 & Profit Change & 2.96 \\
\hline & Source of Revenue & 2.17 & Source of Revenue & 2.14 \\
\hline & Explore/Efficiency & 2.19 & Explore/Efficiency & 2.43 \\
\hline & New Markets & 2.13 & New Markets & 2.22 \\
\hline & New Products & 1.77 & New Products & 1.19 \\
\hline \multirow{3}{*}{ Low } & New Mfg. Systems & 3.28 & New Mfg. Systems & 3.35 \\
\hline & New Mgmt. Systems & 2.14 & New Mgmt. Systems & 2.02 \\
\hline & New Skills & 2.18 & New Skills & 2.07 \\
\hline & \multicolumn{2}{|c|}{ Quadrant 1 (12 firms) } & \multicolumn{2}{|c|}{ Quadrant 2 (35 firms) } \\
\hline & Tran & ion & $\begin{array}{l}3.63 \\
\text { adership Scores }\end{array}$ & \\
\hline
\end{tabular}

a 1 indicates all revenue from traditional, long term sources and a 5 indicates that 10 percent or more of the firm's revenue derived from products and markets that were new to the firm, a percentage that had been growing. As Table 1 shows, firms in the high transformational leadership group had mean scores on both 
scales significantly higher than those firms with low transformational leadership scores. The data in Table 1 also support Hypothesis 4, which predicts that the high transformational leadership firms would report a greater increase in the sources of its revenue and a growth in the overall level of its revenue in the five years leading up to the study than would the low transformational firms.

A test of Hypothesis 5, which predicts that changes in profit would be highest in firms headed by leaders who received high transactional rather than high transformational leadership scores, is not supported by the data in Table 1. The relationship between leadership and profit is more clearly suggested by the data as presented in Table 2. Table 2 divides the 91 firms into four quadrants according to their scores on transformational leadership (high and low transformational leadership) and their scores on transactional leadership (high and low transactional leadership). As the data in Table 2 indicates, the highest scores for change in profits was reported for those firms in quadrant 4 which contains the 20 firms in which the owners scored above the mean on both transformational and transactional leadership. The firms in quadrant 4 also reported the most positive changes in revenue.

These relationships are affirmed in the correlation matrix shown in Table 3. As this table shows, transformational leadership is positively related to revenue change over the five years leading up to the study, positively related to profit change, and positively related to new revenue sources. The correlations also indicate that transactional leadership was also positively related to revenue and profit change. The magnitude of the linkages between the two leadership types and revenue and profit change was quite different, however, with a correlation of .524 between transformational and revenue change compared to a .283 between revenue change and transactional. The strength of the linkages were reversed in the case of profit change however, with a correlation of .269 between profit change and transformational and a .398 between profit change and transactional leadership, a relationship also suggested in Table 2.

Table 3: Means and Correlations

\begin{tabular}{|c|c|c|c|c|c|c|c|c|c|c|}
\hline & Mean & 1 & 2 & 3 & 4 & 5 & 6 & 7 & 8 & 9 \\
\hline 1. Transform & 3.31 & & & & & & & & & \\
\hline 2. Transact & 3.63 & .018 & & & & & & & & \\
\hline 3. Rev-Change & 3.08 & $.524^{\star}$ & $.283^{*}$ & & & & & & & \\
\hline 4. Profit Change & 2.89 & $.269^{*}$ & $.398^{*}$ & $.654^{*}$ & & & & & & \\
\hline 5. Rev-Source & 3.03 & $.687^{\star}$ & -.007 & $.551^{*}$ & $.327^{\star}$ & & & & & \\
\hline 6. New Mkts & 2.99 & $.681^{*}$ & -.008 & $.503^{*}$ & $.249^{*}$ & $.939^{*}$ & & & & \\
\hline 7. New Prods & 2.80 & $.761^{*}$ & .033 & $.586^{*}$ & $.272^{*}$ & $.799^{*}$ & $.840^{*}$ & & & \\
\hline 8. New Mfg-Sys & 3.57 & $.324^{*}$ & .006 & $.224^{*}$ & .057 & $.393^{*}$ & $.413^{*}$ & $.449^{\star}$ & & \\
\hline 9. New Mgt-Sys & 2.94 & $.744^{\star}$ & .026 & $.531^{*}$ & $.252^{*}$ & $.692^{*}$ & $.683^{*}$ & $.803^{*}$ & $.349^{\star}$ & \\
\hline 10. New Skills & 2.96 & $.737^{\star}$ & .030 & $.513^{*}$ & $.234^{*}$ & $.671^{*}$ & $.660^{*}$ & $.781^{\star}$ & $.325^{\star}$ & $.966^{*}$ \\
\hline 11. Explr/Exploit & 3.03 & $.664^{*}$ & -.008 & $.476^{*}$ & $.231^{*}$ & $.922^{*}$ & $.976^{*}$ & $.820^{*}$ & $.423^{*}$ & $.665^{\star}$ \\
\hline
\end{tabular}

${ }^{*}$ Correlation is significant at .05 level.0

The correlations shown in Table 3 reveals a contrast in the relationship between the two leadership types and the five organizational change variables (new 
markets, new products, new manufacturing systems, new management systems, and new skills and capabilities). While positive and significant relationships are indicated with transformational leadership and each of these five variables there is no indication of significant linkage between these five and transactional leadership.

\section{Discussion}

The owners of small firms facing a tide of low-cost, high-quality foreign competitors face a difficult dilemma. Some will stick with their existing domains and focus on improving efficiencies. Others will explore new domains and focus on the development of new products and markets. Many will chose the more cautious of the two strategies, for reasons that are readily comprehensible. As Crossan and Berdrow note, the choice between these will "generally resolve with a bias towards exploitation" (2003:1103). Faced with discontinuous change many managers find themselves unable to turn away from traditional practices (Gilbert, 2005), perhaps because they failed to see a need for change until it was too late (Weitzel \& Jonsson, 1989) or, if aware, lacked the capabilities needed to "integrate, build, and reconfigure internal and external competences" (Eisenhardt \& Martin, 2000: 1106) needed to pursue new opportunities. "More than a few organizations have not even tried to initiate needed changes because the managers involved were afraid that they were simply incapable of successfully implementing them" (Kotter \& Schlesinger, 1979: 107).

For any firm, large or small, the effort required for such a transformation is arduous, path dependent, and weighted down by existing resource endowments (Lavie, 2006) and the 'sticky nature' of organizational capabilities (Helfat, 2003). The risks associated with the development of new products and entry into new markets, difficult for a large firm, loom much larger for a small one with more limited resources. Kalafsky and MacPherson's study (2002) of the U.S. machine tool industry found a significant size-based variation, with the smaller firms less able to implement the innovation and diversification strategies that were successful among larger machine tool firms.

This study shows that small firms are able to initiate and implement significant levels of change all across their operations, in their traditional markets and products, in their manufacturing and management systems, and in their repertoire of skills and knowledge. In this study, the critical enabling element was the transformative influence of the firms' owners. Transformational owners appear to be much more likely to create the nutrient rich environments (Shapero, 1982) in which employees will feel confident of their ability to move outside their familiar routines and embark on the riskier if more promising strategies of organizational change. These were leaders whose employees rated them high on behaviors such as 'encourages me to express my opinions,' 'enables me to think about old problems in new ways,' 'forced me to rethink some of my own ideas,' and 'provided me with new ways to look at things.' 
This aptitude led to innovation all across the firms' operations. The firms with transformational owners developed new product offerings, entered new markets, developed new methods of production, embraced new organizational and managerial systems, and learned new skills at significantly higher levels than the firms where the owners were not perceived as transformational. The performance implications regarding the value of transformational leadership and the corresponding transformation of their firms are clear. These were the organizations reporting the best financial performance, measured in terms of growth in revenue and profit. They also reported new sources of revenue, suggesting that a strategy of change led to more successful efforts at new market entry and new product development.

Findings such as these do not negate the value of the transactional elements of a manager's set of skills, however. It was the combination of high transformational and high transactional behaviors that resulted in the most positive changes in both revenue and profits. The combination of adaptability and operational efficiency inherent in these two leadership behaviors is evident in specific components of organizational change as well. The firms in which the owners were rated as high in both behaviors also scored highest in the development of new management systems, in the acquisition of new skills and knowledge, and were also high in new market entry, new product development, and new manufacturing systems. The ability of a leader to manifest both leadership types, however, is apparently a difficult task, as the staff in only 20 of the ninety-one firms reported such a combination. Moreover, slightly less than half of the sample firms, forty four, reported leaders high in transformational leadership.

A review of the items measuring transformational leadership may suggest why behaviors with such obvious benefits are not more common. Some of them, 'encourages me to express my ideas and opinions,' 'has forced me to rethink some of my own ideas..., 'has provided me with new ways to think about things,' 'gives personal attention to members who seem neglected,' or 'can be counted on to express appreciation when you do a good job,' insofar as they are observable behaviors, lend themselves to modeling by others who aspire to organizational transformation. Others, however, may be less amendable to copying, for example 'is an inspiration,' 'I have complete faith in him/her,' 'inspires loyalty,' or 'makes everyone enthusiastic.'

In any case, the benefits to venturing into new markets, through the development of new markets or new products, seem compelling. The firms that reported the highest scores on new sources of revenue and an orientation towards exploration of new opportunities outperformed financially firms whose orientation was to exploit existing resources and focus on existing sources of revenue. While the familiarity of exploitation of traditional resources is tempting, it can result in reliance on skills that are of decreasing value in the market. "It is quite possible for competence in an inferior activity to be great enough to exclude superior activities with which an organization has little experience" (Herriott, Levinthal, \& March, 1985: 73). For firms confronting industry wide decline the ability to 
acquire and utilize new resources is a strategically significant resource to be pursued (Grant, 1996; Miller, 1996; Volberda, 1996).

A limitation of this study is its cross sectional design. This makes it impossible to determine if transformational leadership led to the types of change depicted or if a history of change in markets, products, and capabilities resulted in a perception that the organization's leader was transformational. It may also be the case that the two, transformational leadership and organizational change, emerged simultaneously, the one encouraging the other. What is clear, however, is that the two do occur together: high transformational leadership is associated with higher levels of successful organization change. Another limitation is the inability to suggest how effective transformational leadership may be in periods of stability. In as much as long periods of stability in either markets or technology appear to be the exception to the dynamic turbulence that characterizes the contemporary economy this may not be a significant issue. Finally, a single industry focus limits the generalizability of findings.

Future research in this area should attempt a longitudinal exploration of the relationship among the variables and, perhaps, apply itself to a more diversified assortment of firms. It should also be interesting to break down the component parts of transformational leadership to tease out which might have the greatest benefit. This might enable researchers and managers to identify specific sets of behaviors that can be learned and applied in a variety of settings.

\section{References}

Ajzen, I. (1991). The theory of planned behavior. Organizational Behavior and Human Decision Processes, 50, 179-211.

Anand, J., \& Singh, H. (1997). Asset redeployment, acquisitions and corporate strategy in declining industries. Strategic Management Journal, 18, 99118.

Avolio, B. J., Bass, B. M., \& Jung, D. I. (1999). Re -examining the components of transformational and transactional leadership using the multifactor leadership questionnaire. Journal of Occupational and Organizational Psychology, 72, 441-462.

Barney, J. B. (1986). Organizational culture: Can it be a source of sustained Competitive advantage? Academy of Management Review, 11(3), 656665.

Bass, B. M. (1998). Transformational leadership: Industry, educational, and military impact. Mahwah, NJ: Lawrence Erlbaum Associates.

Bass, B. (1985). Leadership and performance beyond expectations. New York: The Free Press. 
Bass, B. M. (1998). Transformational leadership: Industry, educational, and military impact. Mahwah, NJ: Lawrence Erlbaum Associates.

Bass, B. M. (1990). Bass and Stogdill's handbook of leadership: Theory, research and managerial applications. New York: Free Press.

Benner, M. J., \& Tushman, M. L. (2001). Exploitation, exploration, and process management: The productivity dilemma revisited. Academy of Management Review, 2, 238-256.

Boal, K. B., \& Bryson. J. M. (1988). Charismatic leadership: A phenomenological and structural approach. In J. G. Hunt, B. R. Baliga, H. P. Dachler, \& C. A. Schriesheim (Eds.). Emerging leadership vistas (11-28). Lexington, MA: Lexington Books.

Burgelman, R. A. (1984). Designs for corporate entrepreneurship. California Management Review, 26, 154-166.

Bycio, P., Hackett, R. D., \& Allen, J. S. (1995). Further assessments of Bass's conceptualization of transactional and transformational leadership. Journal of Applied Psychology, 80, 468-478.

Crossan, M. M. \& Berdrow, I. (2003). Organizational learning and strategic renewal. Strategic Management Journal, 24, 1087-1105.

Crossan, M., Lane, H., \& White, R. (1999). An organizational learning framework: From intuition to institution. Academy of Management Review, 24, 522538.

Dutton, J. E. (1993). The making of organizational opportunities: An interpretive pathway to organizational change. In B. M. Staw \& L. L. Cummings (Eds.), Research in organizational behavior (pp. 195-226). Greenwich, CT: JAI Press.

Eisenhardt, K. M., \& Martin, J. A. (2000). Dynamic capabilities: What are they? Strategic Management Journal, 21, 1105-1121.

Fiol, C. M, \& Lyles, M. A. (1985). Organizational learning. Academy of Management Review, 10, 803-813.

Gilbert, C. G. (2005). Unbundling the structure of inertia: Resource versus routine rigidity. Academy of Management Journal, 48, 741-773.

Gordon, G. (1991). Industry determinants of organizational culture. Academy of Management Review, 16, 396-415.

Grant, R. M. (1996). Prospering in dynamically-competitive environments: 
Organizational capability as knowledge integration. Organization Science, 7, 375-387.

Guzzo, R. A., Yost, P. R., Campbell, R. J., \& Shea, G. P. (1993). Potency in groups: Articulating a construct. British Journal of Social Psychology, 32, 87-106.

Helfat, C. E. (2003). Stylized facts regarding the evolution of organizational resources and capabilities. In C. E. Helfat (Ed.), The SMS Blackwell handbook of organizational capabilities: Emergence, development, and change (pp. 1-11). Malden, MA: Blackwell.

Herriott, S. R., Levinthal, D. A., \& March, J. G. (1985). Learning from experience In organizations. American Economic Review, 75, 298-302.

Hitt, M. A., Keats, B. W., \& DeMarie, S. M. (1998). Navigating in the new competitive landscape: Building strategic flexibility and competitive advantage in the $21^{\text {st }}$ century. Academy of Management Executive, 12, $22-42$.

Holmqvist, M. (2004). Experiential learning processes of exploitation and exploration within and between organizations: An empirical study of product development. Organization Science, 15, 70-81.

Howell, J. M. \& Avolio, B. J. (1993). Transformational leadership, transactional leadership, locus of control, and support for innovation: Key predictors of consolidated-business-unit performance. Journal of Applied Psychology, 78, 891-902.

Jansen, K. J. (2004). From persistence to pursuit: A longitudinal examination of momentum during early stages of strategic change. Organization Science, $15,276-294$.

Kalafsky, R. V., \& Macpherson, A. D. (2002). The competitive characteristics of US manufacturers in the machine tool industry. Small Business Economics, 19, 355-370.

Keller, R. T. (1992). Transformational leadership and the performance of research and development project groups. Journal of Management, 18, 489-501.

Kotter, J. P., \& Schlesinger, L. A. (1979, March-April). Choosing strategies for change. Harvard Business Review 106-114.

Krueger, N. F. (2000, Spring). The cognitive infrastructure of opportunity emergence. Entrepreneurship: Theory and Practice, 5-21.

Lavie, D. 2006. Capability reconfiguration: An analysis of incumbent responses to 
technological change. Academy of Management Review, 31, 153-174.

Lumpkin, G. T., \& Dess, G. G. (1996). Clarifying the entrepreneurial orientation construct and linking it to performance. Academy of Management Reviews 20, 135-172.

March, J. G. (1991). Exploration and exploitation in organizational learning. Organization Science, 2, 71-87.

McGrath, R. G. (2001). Exploratory learning, innovative capacity, and managerial oversight. Academy of Management Journal, 44, 118-131.

Moni, A. H. (1998). Small firms exporting: How effective are government export assistance programs? Journal of Small Business Management, 36, 1-16.

Parker, B., \& Helmes, M. M. (1992). Generic strategies and firm performance in a declining industry. Management International Review 32(1), 23-40.

Pawar, B. S., \& Eastman, K. K. (1997). The nature and implications of contextual influences on transformational leadership: A conceptual examination. Academy of Management Review, 22: 80-109.

Prahalad, C. K., \& Bettis, R. A. (1986). The dominant logic: A new linkage between diversity and performance. Strategic Management Journal, 7 , 485-501.

Quinn, R. E. (1988). Beyond rational management: Mastering the paradoxes and competing demands of high performance. San Francisco: Jossey-Bass

Recker, G., Goldsby, M. G., \& Neck, C. P. (2002). Organizational survival within a declining industry: An analysis of a single sex boarding school. The International Journal of Educational Management, 16, 137-143.

Robbins, D. K., \& Pearce, J. A. (1992). Turnaround: Retrenchment and recovery. Strategic Management Journal, 13, 287-309.

Rouse, M. J., \& Daellenbach, U. S. (1999). Rethinking research methods for the resource-based perspective: Isolating sources of sustainable competitive advantage. Strategic Management Journal, 20, 487-494.

Rowe, G. (2001). Creating wealth in organizations: The role of strategic leadership. Academy of Management Executive, 15, 81-94.

Seltzer, J., \& Bass, R. M. (1990). Transformational leadership: Beyond initiation and consideration. Journal of Management, 16, 693-703.

Shamir, B., House, R. J., \& Arthur, M. B. (1993). The motivational effects of charismatic leadership: A self-concept based theory. Organizational 
Science, 577-594.

Shapero, A. (1982). Social dimensions of entrepreneurship. In C. Kent (Ed.), The encyclopedia of entrepreneurship (pp. 72-90). Englewood Cliffs, NJ: Prentice Hall.

Sitkin, S. B. (1992). Learning through failures: The strategy of small losses. Research in Organizational Behavior, 14, 231-266.

Staw, B. M., Sandelands, L. \& Dutton, J. (1981). Threat rigidity effects in organizational behavior. Administrative Science Quarterly, 26, 501-524.

Stopford, J. M., \& Baden-Fuller, C. (1990). Corporate rejuvenation. Journal of Management Studies, 47, 399-415.

Thompson, J. D. (1967). Organizations in action. New York: McGraw-Hill.

Tichy, N. M., \& Devanna, M. A. III. (1986). The transformational leader. New York: Wiley.

Tichy, N. M., \& Ulrich, D. O. (1984). SMR Forum: The leadership challenge-a call for the transformational leader. Sloan Management Review 26, 59-68.

Tripsas, M., \& Gavetti, G. (2000). Capabilities, cognition, and inertia: Evidence from digital imaging. Strategic Management Journal, 18, 509-553.

Tushman, M. L., \& O'Reilly, C. (1996). Ambidextrous organizations: Managing evolutionary and revolutionary change. California Management Review, $38,8-30$.

Vera, D., \& Crossan, M. (2004). Strategic leadership and organizational learning. Academy of Management Review, 29, 222-240.

Viator, R. E. (2001). The relevance of transformational leadership to nontraditional accounting services: Information systems assurance and business consulting. Journal of Information Service, 15(2), 99-125.

Volberda, H. W.(1996). Toward the flexible form: How to remain vital in hypercompetitive environments. Organization Science. 7(4), 359-374

Volberda, H. W., Baden-Fuller, C., \& van den Bosch, F. (2001). Mastering strategic renewal: Mobilizing renewal journeys in multi-unit firms. Long Range Planning, 34, 159-178.

Yukl, G. \& Van Fleet, D. D. (1992). Theory and research on leadership in Organizations. In Marvin D. Dunnett and Leaetta M. Hough (eds.), Handbook of Industrial and Organizational Psychology (pp. 147-197). Palo Alto, CA: Consulting Psychologist Press. 
Weitzel, W., \& Jonsson, E. (1989). Decline in organizations: A literature integration and extension. Administrative Science Quarterly, 34, 91-109. 


\section{Appendix - MLQ Survey Items}

\section{Transformational Leadership}

Charismatic Leadership

- Makes everyone around him/her enthusiastic about assignments.

- I have complete faith in him/her.

- Encourages me to express my ideas and opinions.

Inspirational Motivation

- Is an inspiration to us.

- Inspires loyalty to him/her.

- Inspires loyalty to the organization.

Intellectual Stimulation

- His/her ideas have forced me to rethink some of my own ideas, which I had never questioned before.

- Enables me to think about old problems in new ways.

- Has provided me new ways of looking at things, which used to puzzle me. Individualized Consideration

- Gives personal attention to members who seem neglected.

- Finds out what I want and tries to help me get it.

- You can count on to express his/her appreciation when you do a good job.

\section{Transactional Leadership}

Contingent Reward

- Tells me what to do if I want to be rewarded for my efforts

- There is close agreement between what I am expected to put into the group effort and what I can get out of it.

- Whenever I feel like it, I can negotiate with him/her about what I can get from what I accomplish.

\section{Management by Exception}

- Asks no more of me that what is absolutely essential to get the work done.

- It is all right if I take initiatives but he/she does not encourage me to do so.

- Only tells me what I have to know to do my job.

Source: Vera \& Crossan, 2004: 236. Adapted from Bass, 1985, 1998. 